\title{
ARTICLE \\ AMONG FOUR HOTELS: ANTI-RACIST PUBLIC POLICY IN BRAZIL.
}

Sérgio José Custódio ${ }^{1}$

ORCID: https://orcid.org/0000-0001-9019-8564

\begin{abstract}
:
The article explores analytical possibilities of the relationship between racism and antiracism. It does so through occurrences of institutional racism in hotels and corresponding anti-racist actions. The approach is interdisciplinary, covering history, psychology, political sociology, literature, cinema. Is there a variation of racism over time? Is there a variation of anti-racism over time? What remains? Is there a relationship between racism and fascism in Brazil? In what way does this show up? Is there a relationship between anti-racism and public policy? The analysis seeks to reflect on these issues. The article argues that anti-racist action is fundamental for the emergence of public policy and for the fight against fascism, as racism structures fascism.
\end{abstract}

\section{KEYWORDS:}

Public policy, racism, anti-racism, Overlook, institutional racism, fascism, hotel.

\section{RESUMO:}

O artigo explora possibilidades analíticas da relação entre racismo e antirracismo. O faz por intermédio de ocorrências de racismo institucional em hotéis e de correspondentes ações antirracistas. A abordagem é interdisciplinar, abrange história, psicologia, sociologia política, literatura, cinema. Há variação do racismo no tempo? Há variação do antirracismo no tempo? O que permanece? Há relação entre o racismo e o fascismo no Brasil? De que maneira isso aparece? Há relação entre antirracismo e política pública? A análise busca refletir sobre essas questões. $\mathrm{O}$ artigo sustenta que a ação antirracista é fundamental para o surgimento de uma política pública e para o combate ao fascismo, na medida em que o racismo estrutura o fascismo.

\section{PALAVRAS-CHAVE:}

Política pública, racismo, antirracismo, Overlook, racismo institucional, fascismo, hotel.

\footnotetext{
${ }^{1}$ Programa de Pós-Graduação Humanidades, Direitos e Outras Legitimidades, Faculdade de Filosofia, Letras, Ciências Sociais e História da Universidade de São Paulo (FFLCH-USP), São Paulo, Brasil. O autor é graduado em Ciências Econômicas pela Unicamp, mestre em Educação pela USP e membro do Grupo de Estudos e Pesquisas das Políticas Públicas para a Inclusão Social (GEPPIS-USP). Email: sergiojosecustodio@usp.br.
} 


\section{RESUMEN:}

El artículo explora las posibilidades analíticas de la relación entre racismo y antirracismo. Lo hace a través de ocurrencias de racismo institucional en hoteles y las correspondientes acciones antirracistas. El enfoque es interdisciplinario, cubriendo historia, psicología, sociología política, literatura, cine. ¿Existe una variación del racismo a lo largo del tiempo? ¿Existe una variación del antirracismo a lo largo del tiempo? ¿Lo que queda? ¿Existe una relación entre racismo y fascismo en Brasil? ¿Cómo aparece esto? ¿Existe una relación entre el antirracismo y las políticas públicas? El análisis busca reflexionar sobre estos temas. El artículo sostiene que la acción antirracista es fundamental para el surgimiento de políticas públicas y para la lucha contra el fascismo, ya que el racismo estructura el fascismo.

\section{PALABRAS CLAVE:}

Política pública, racismo, antirracismo, Overlook, racismo institucional, fascismo, hotel.

\footnotetext{
"To apprehend racism in the country, as it produces and was historically produced by the State and by the wider society - of course, aiming to fight it - it is not enough to assume interpersonal practices of its expression, such as prejudice. Today, in addition to its interpersonal intermediations, racism is also maintained and constructed within the scope of institutions" ${ }^{2}$
}

\section{INTRODUCTION.}

The subject of this article is racism and anti-racism in Brazil. This opens up a broader research agenda, however. Therefore, only a few particular dimensions will be explored here: the dynamics of institutional racism, perceived through symptomatic episodes in hotels, a private institution; the conceptual dynamics of the racism/anti-racism pair that involves these cases; the possible connections and theoretical extrapolations between the pair racism/anti-racism and fascism/antifascism.

\footnotetext{
${ }^{2}$ Rosemberg (2017, p. 132).
} 
The theoretical perspective that informs the article is interdisciplinary, more specifically, public policy; history; psychoanalysis; the study of institutions and the violence of organizations and the aesthetics of the Latin American literary fantastic, the aesthetics of the absurd, history. The methodology is comparative, through document research and content analysis from secondary and primary sources, such as diaries, newspapers, books.

\section{THE QUESTIONS IN THE ARTICLE.}

There have been several episodes of racism and fascism in Brazilian society in recent years (Lourenço, 2006; Ramos, 2017). Are they the same racism and fascism as in the past? What theoretical elements are needed to think about racism and anti-racism in Brazil? Is it anti-racist action that generates anti-racist public policy or is anti-racist public policy falling from the sky, like the work of the enlightened? What is the relationship between racism and fascism in Brazil?

\section{HYPOTHESES}

There is a variability of racism and anti-racism throughout Brazilian history. Two types of racism and two types of fascism, at least, are inscribed in the history of Brazil in the 20th and 21st centuries. For each typology, an anti-racism and an antifascism are inscribed, as a complementary pair, at least under the risk of weakening the fight against social dominance. As a result of the hard struggle between anti-racism and racism, public policy sprouts, each with its particular anti-racist power, given by the game of forces in the political field. From racism sprouts fascism.

\section{HOTELS.}

An institution such as a hotel can also be the abode of many ghosts, dead and alive, as in that Overlook hotel from Stanley Kubrick's film "The Shining, 1980", inspired by the book of the same name by Stephen King (2020 [1977]). The ghost of racism surrounds institutions, hotels, their institutionality, their organizational logic.

Just like interest in a bank account, its strength accumulates secretly and silently, to parody a metaphor by King (2020, p. 439), where "strength, presence, form" are just words for something that wears many masks, but can be one thing: institutional racism. In the book, black chef Richard Hallorann saves the white lives of mother and child from the Overlook Hotel fire. Newspapers insinuate, however, soon after the fire, that 
he was the main suspect in what happened (King, 511-512), which is denied by Winnifred Torrance, the saved white woman, "The fire was not started. The only crime that mr. Hallorann committed was to save my life and my son's. And if he's convicted of it, I'll be happy to serve the sentence for him." (King, 514). The boiler had exploded.

Halorrann was not convicted. He had faced terrifying forces to reach the Overlook Hotel, in heavy snow, at the top of the United States, at an altitude of 3200 meters, in the Rocky Mountains of Colorado.

\begin{abstract}
And that's when the scent of orange hit him full force, with murderous rage: (GET OUT OF HERE YOUR DIRTY CRIOLE DON'T GET IN YOUR CRIOLE GO BACK OR WE'LL KILL YOU WE'LL HANG YOU IN A TREE YOU DARN CRIOLE AND THEN WE'LL BURN YOUR BODY THAT'S WHAT WE DO WITH CRIOLELS SO BACK IMMEDIATELY). Then the car hit a barrier, skidded and stopped. The rear wheels turned. Hallorann yelled into the confined space of the car. The message did not come to him in words but in a series of drawings that formed words, thrown at his head with terrible force. He took his hands off the steering wheel to push the images away. (King, 2020, p. 411-412).
\end{abstract}

In the aforementioned film, Hallorann is killed in the hotel by a white man. As in the movie, a hotel is a space for the confrontation of eyes.

"We know that the subject is constituted in the gaze of the other", from the gaze of the parental figures, the effects of racism can already be seen, "a gaze that can be continuously reinforced by the different gazes that this individual will encounter throughout his development". (Silva, 2017, p.82-84). Racism is the ghost that haunts existences and mobilizes the subject's psychic forces in a game of life and death.

The hotel is a place for the confrontation of psyches, which can mix up the symbolic, the real and the Lacanian imagination, as in the case of the pathogenic defense mechanisms present in subjects and institutions, such as displacement, regression, projection, isolation, reactive formation, rationalization, repetition, "symptoms" that can indicate repressions, denials.

Because racism is a denial of latinoamefricanity, said Lélia Gonzales. Individual psychology is social psychology, said Freud. Fanon in "Black skin, white masks" and "The Wretched of the Earth" mobilizes the necessary impulses to fight racism, colonialism, in the anti-colonial war of gazes. Fanon, who knows Freud, does not only mobilize the weapons of love to fight racism, colonialism, in his life and death struggle (Guimarães, 2013). But, you can not see racism, 
Racism is a phenomenon present in several contemporary societies, latent in culture, institutions and in the daily relationships between human beings. However, there are people who do not see it or pretend not to see it. (Munanga, 2017, p. 33).

And racist kink persists throughout the long history of Brazil and is always regenerated, racism is always regenerated, like the ghost of the Overlook hotel, as studied by Brazilians scholars Neusa Santos Souza, Izildinha Baptista Nogueira and many others.

Furthermore, racism also shines through other shades of narcissism that can inhabit institutional environments, such as the narcissism of small differences, also present in Freud's work and "through which it is possible to connect a large number of people through love, as long as there are others so that aggressiveness can be externalized" (Kon, 2017, p. 20). Bonds of love and hate can inhabit an institution, like a hotel, like the Overlook.

The undesirable, the foreign, "the negatively unequal" is the useful non-Self that clashes "when we adopt as a standard of truth and beauty the narcissistic ideal self (in our case that of the colonizing white), what Freud called "purified pleasure ego ". (Kon, 2017 , p. 20).

Dressed in a "purifying pleasure ego" or institutional narcissism, a hotel has a narcissistic dimension that operates through the subjects that make up the organizational hierarchy and also through their ghosts.

The presence of a black body in a hotel can trigger the invisible racist alarm, the institution's fierce narcissistic vocations and question the way it sees itself in the mirror, as well as the context in which the institution is inserted, as its tensions express the tensions of a given time in history and its consequences. History does not paralyze the psyche, nor racism,

It has a trajectory and several histories, which must be interpreted according to times, cultural models and power structures of the societies that practice it. Despite obeying the same logic of hierarchization of "others", racism passes, over the years, through a complexity of mutations in its social, cultural and discursive figures. (Munanga, 2017, p. 33). 


\title{
5. THE US HOTEL IN THE MIDDLE OF THE PATH OF THE BRAZILIAN ABOLITIONIST ANDRÉ REBOUÇAS IN 1873.
}

There are many interpretations about unfinished abolition in Brazil. The abolition of 1888 was that of two short paragraphs: slavery is declared extinct, provisions to the contrary are revoked, and that's it. Abolition was the result of a long journey of struggle.

Blacks Luiz Gama, José do Patrocínio and André Rebouças, the latter name of the famous avenue of access to the University of São Paulo campus, were among the protagonists of the struggle for the abolition of black enslavement in the second half of the 19 th century.

Luiz Gama with the word,

\begin{abstract}
Illustrated editor: I have just read, without surprise, but with regret, the written grievance, published in today's (...) Province [of São Paulo], against the distinguished citizen José do Patrocínio. In us, even color is a defect, an unpardonable vice of origin, the stigma of a crime; and they go so far as to forget that this color is the source of wealth for thousands of robbers, who insult us; that this conventional color of slavery, as the speculators suppose, like the earth, across the dark surface, encloses volcanoes, where the sacred fire of freedom burns. I came [to remind] the citizen's offender José do Patrocínio why we, the abolitionists, animated by a single belief, guided by a single idea, form a single family, aiming at a single sacrifice, fulfilling a single duty. José do Patrocínio, for his high intelligence, for his pride, for his patriotism, for the nobility of his character, for his honesty, which have no colors, became a creditor of esteem and is worthy of praise from good men. (Ferreira, 2011, p. 151)
\end{abstract}

The Golden Law, how was called the abolition law from May, 131888 because of the gold pen of the princess, would silence the crime of continuous and illegal enslavement of about 700,000 black men and women, of all ages, made in default of the legal public policy law of 1831 (Chalhoub, 2012) until 1850, which left the wound of institutional violence open in Brazil now an independent nation-state throughout the 1800s. 
For historian Luis Felipe de Alencastro, the condition of the enslaved black, the enslaved black in the new nation-state was peculiar: the slave master did not want to see the enslaved arrested, but wanted permission to beat and dominate by violence, thus the enslaved black, thing, the private property of the patriarchal master, is outside the penal code because it cannot be arrested, but within the violence of dominance by the slave masters' own hands.

In other words, violence is institutionalized against some, against the black, the black woman. For that, there was a fertile ground of more than 300 years of black enslavement, land to plant and reap a new crop of violence, always institutionally renewed, always on black and indigenous bodies more than others.

It would be an extemporaneous luxury to just call it racism, it would be almost alienation not to see the roots of racism in Brazil there. There are both sides to the dispute. There is the terror of slavery over black bodies that struggle in every way against violent oppression.

\begin{abstract}
When, however, by an invincible force, by an indomitable impetus, by a sovereign movement of rebellious instinct, they rise up, like reason, and kill their lord, as Lusbel would kill God, they are imprisoned; and there, virtue is exasperated, piety is contracted, freedom is constrained, indignation is revolting, patriotism is armed: three hundred citizens gather, adjust, march straight to prison: and there (oh ! the whole world must applaud) the knife, the stick, the hoe, the axe, bravely kill four men, even less four blacks; or even less to four slaves bound in a prison. (Ferreira, 2011, p. 154-155).
\end{abstract}

Of those three from the abolitionist struggle in Brazil in the middle of the institutional violence floor of slavery, Rebouças, a "scalded cat" by his father and under his protection, had managed to graduate in engineering, in a way, "deviating" from his color, like an aristocrat in the Empire of Brazil, in the slave court of Dom Pedro II.

But this idealized vision, this self-produced mirror, this denial, would be shaken at the Washington Hotel in New York. You must see to believe.

A friend recounts his "successful triumphs", "noise and renown immediately surrounded the first steps and undertakings of the emeritus and daring engineer [...] He had jobs and money abounding and, as was natural, he had plenty of friends and admirers.. .". Unlike Gama, Rebouças reached a high social position that eclipsed his color. Between the apparent indifference to her in the high circles - the "my English" from Itaboraí - and the self-camouflage, he was able to reach 
a mature age without referring to his own skin or to the intimate confessional, the personal diary. That changed in New York. He had passed through Europe, in operas and aristocratic receptions, those of the Brazilian chancellor in London, those in Venice and Milan, arm in arm with Carlos Gomes. And so in Vienna and Paris. On his return, in June 1873, he landed in the USA. Right in the Yankee power, his model of progress, he experienced the same social subordination that Gama had purged in São Paulo. In Europe and Brazil, in the chic circles, he turned a deaf ear to jokes, obstacles, antipathy and even to anonymous letters, revealing "the quality of me as a mulatto". He was above all an aristocrat, who happened not to be white. In the bourgeois metropolis, averse to noble labels, color overcame nobility. Race operated as a social limit and he found himself chased away from hotels in New York: "After a few attempts, I understood that it was the difficulty of color that was the cause of the refusals to stay in a room". In the end, through the Brazilian consulate, he obtained a place at the Washington Hotel on the condition that he eat in his room and never show up at the restaurant. It was "a very dirty room on the third floor [...]. In the morning I was forced to take a shower in a barbershop". He couldn't accompany a friend to his favorite program: "The loss of color prevented me from watching the show at the Gran Opera House". On June 16 he slept hungry, such was the veto of restaurants. He fled to Pennsylvania. He found Philadelphia dirty, Philadelphia found Rebouças black: "The color loss forced me to have a meal in our room". When interventions from friends won him a place at the French 's Hotel in New York, he tried to reassume the identity of an aristocrat, complaining of "a servant service far inferior to that of the hotels in Europe". But his identity was cracked. The United States left mirror of it. Intense experience of a society in which, in the absence of aristocratic hierarchies, color had become a mark of distinction, differentiating and subordinating, a stigma. An appreciator of symmetries, exactly two years after freeing the last slaves from his house, he realized that he was also the offspring of the African trade. The condition lasted indelibly on the skin. This Rebouças learned, literally, in the flesh. (Alonso, 2016, p. 110-111).

The institutional racism of the Hotel Washington, New York, in 1873, 15 years before the unfinished abolition of slavery in Brazil, on the one hand informs about the American racial hierarchy and its institutional enjoyment, on the other hand it exposes the complex institutionality of Brazilian racism through the written diary of the black traveler André Rebouças studied by Alexandro Dantas Trindade and Angela Alonso.

It is important here to establish a relationship with the perspectives that inform this article. It is evident in the passage that through the Hotel Washington, André Rebouças' "mirror" breaks. This indicates a before and an after the mirror breaks. In both moments, the subject looks for strategies for insertion in a racist society that enslaves black people, legally or illegally.

At first, there is an elaborated very particular psychism: the color is eclipsed, there is a self-camouflage taken to mature age, one turns a deaf ear to jokes, one 
overcomes institutionalized social obstacles in Brazil against blacks, one flees from antipathies, of teasing and cursing as an anonymous letter.

In other words, a practically white ideal-I is built, shielded by a fragile armor, superimposing an imaginary subject on a real subject, as a survival strategy in the Brazilian aristocracy that signals some minimum comfort zone. It is also a strategy for social ascension and maintenance of the social status achieved by the father.

Perhaps this strategy was successful to "dribble" the steamroller of institutional racism or to escape the death of common violence against blacks.

Before Kafka, locked in his room at the Hotel Washington, André may feel inside the Kafka process, inside a nameless process, but institutional, because it is an institutional mechanism and people play racist roles and it may even be nothing personal, no employee Hotel Washington wants to lose his job, in the end, they follow orders like Eichmann.

The lucrative and not painless narcissism, of seeing a white skin in a black man in the mirror itself, could be explored to the limit in order to seek to extract slivers of benefits in the ongoing institutional process, which only to call racist, may seem nonsense.

However, this particular narcissism, which perhaps does not fit into the very frame of the subject's narcissism, would not work in the Washington Hotel in New York. It's another moment, a second moment. The subject perceives his ideal image projected on the mirror to crack, break, fall to the ground.

The psychic remains of slave ships are among the shards of glass that are gathered in their black hands and make them hurt, among other sharp glass that make them hurt.

Through humiliation, hunger, pain, a visceral black emerges for an anti-racist struggle and the challenges of his time in the same André Rebouças. Your right to a room, to see an opera, to eat in a restaurant might scream in your ears.

Another nobility invades the subject who carries the burden of black color in a frame of institutionalized racism. He calls for the support and intervention of the 
Brazilian embassy of the slave empire of the 1800s to help him. He goes from one state to another in the slave-owning USA.

It's not just a hotel, it's the hotels that are like that, institutionally there is no place for blacks. If there were them in Brazil, it wasn't a place for blacks either. Being in a hotel is the institutional mark of distinction. Not being is the exclusion, because,

\begin{abstract}
The search for distinction is inextricably intertwined with prejudices. The distinct is the social opposite of the excluded. The relationships of distinction and exclusion are possible because, between the distinct and the excluded, there is a barrier of prejudice. People are rigidly qualified as "more" or "less", and social distances become almost insurmountable. (Almeida Jr., 2016, p. 236).
\end{abstract}

The organizational logic of institutional racism is concerned with guaranteeing distinction and its barriers, without any other interest in the fate of the excluded. The status quo makes its horns echo not only in the wind, but institutionally, with wellcalculated and very practical logics, like an aseptic "no free rooms" from the bureaucracy's mouth at street level.

Perhaps the episode served André Rebouças to see beyond the mirror. He would viscerally get involved in the fight against black enslavement and for abolition in Brazil. In order to do so, he would need to end slavery, change the law, tangible and intangible institutionality, a task of many hands, of many bodies.

The case illustrates an anti-racist birth from the bowels of racism, which motivates, moves a subject, in their historical situation, pushes a subject out of the subject itself, in a collective intervention on the social world given a deep need - an unconscious volcano erupts simultaneously in time and in the historical moment in various subjects - to change institutional racism, a mission of many hands, of many subjects. The institutional racism of the Washington Hotel in New York mirrored the racism of the State, US and Brazilian. A mirror of the way in which the mechanisms of social dominance operated.

The Hotel Washington is also the hotel of culture that shatters the subject or a conformation of the subject, according to the tensions of instincts/drives/desires versus the harsh and violent rules of culture, as argued by Freud in "Civilization and its Discontents". 
The anti-racism seen from this angle is cultural insubordination with the dominant culture. Institutional racism, on the other hand, is equivalent to a kind of enjoyment of the dominant culture that tries to subordinate the subject-thing as an object of desire. It's war.

\section{THE HOTEL ESPLANADA FROM PRAÇA RAMOS DE AZEVEDO IN SÃO PAULO, THE NO TO ACCOMMODATION BY KATHERINE DUNHAM AND THE FIRST LAW AGAINST RACIAL DISCRIMINATION IN BRAZIL.}

It was not just Zé Carioca that relations between Brazil and the United States were made. One of the great winners of the Second World War, which defeated the fascisms of the 1920s and 1940s, the post-war US government, through its State Department, undertakes aggressive cultural diplomacy around the world, mobilizing artists internally and publicizing the American culture "all around the world". These are the American cultural missions, which involve not only the exchange of artists, but also of scientists and researchers.

Seen from afar, there was an Achilles' heel in certain parts of the established power across the globe, in social dominance. Despite defeating fascism, black apartheid within the US was a scandal, as many black lives were taken in the war on behalf of the US. The same scandal took place in the African colonies. No less scandalous was the social situation of Afro-descendants in various countries, such as Latin America.

Thus, an American cultural mission abroad was not like a cartoon by Zé Carioca, as contradictions surfaced.

Hotels were epicenters of these occurrences.

The world, "This world is a perfect mythology: man is the eternal Sisyphus." (Ferreira, 2011, p. 153), said Luiz Gama in 1880.

Born in 1913, in Algeria, a member of the generation of Europeans who at twenty had Hitler on stage, the Algerian Albert Camus, was in the pendulum between his book "The Myth of Sisyphus", about the European absurdity of the human condition and the creation process of the new book "The Revolted Man". 
Camus rejects Rio de Janeiro's luxury hotels upon his arrival on July 15, 1949, coming for the new French mission in the tropics, to visit Brazil and deliver the conference "The time of the Killers" about Europe.

My choice is offered a room in the embassy's residence, which is deserted, and a luxury hotel like there is everywhere. I run away from the damned luxury hotel and am delighted to find the simplest and most charming of rooms, in an absolutely empty residence. (Pinto, 2019, p. 57).

Remember Algeria, when realizing the real Rio de Janeiro,

The most striking contrast is provided by the luxurious ostentation of the palaces and modern buildings with the slums, sometimes a hundred meters from the luxury, species of bidonvilles clinging to the sides of the hills, without water or electricity, where a miserable black and white population lives. . The women fetch water at the foot of the hills, where they line up, and bring back their supply in aluminum cans, which they carry on their heads like the Kabile women. (Pinto, 2019, p. 57)

Camus goes to the terreiro in Rio de Janeiro along with Abdias do Nascimento, goes to the Teatro Experimental do Negro. The book "O Negro Revoltado", by GRD editions, published in 1968, already mentions in the presentation Camus: first "What is a revolted man? A man who says no. But by denying himself he does not renounce: he is also a man who says yes from the first moment", then "I rebel, therefore we are". (Nascimento, 1968)

It is a key to the importance of collective anti-racist action. An interpretation of the absurdity of the condition of black people in Brazil emerges.

In 1947, the American black scientist Irene Diggs was barred from the Hotel Serrador, which led Abdias do Nascimento, the black movement, a group of white and black artists and intellectuals to a strong anti-racist reaction with a symbolic collective hosting in redress at the Hotel Serrador in Rio.

Because I'm black. Hotel Serrador hastily arranged a yellow excuse that did not convince me. They didn't know, in that hotel, that Dr. Irene Diggs was black, hence the confusion they were in when I presented myself at the reception. (...) I will reveal then what everyone ignores in my country, that is, that this great country where the black race has already produced geniuses and heroes with Henrique Dias, Aleijadinho and others, hides its racial prejudice like the ember under the gray. (Nascimento, 1968, p. 26). 
The hotel would step back and seek to correct racial discrimination. A photo on page 160 of the book "O negro revoltado" (Nascimento, 1968), a title that sounds like a frank tribute to Camus, to Africa, to pan-Africanism, exposes the anti-racist action at the Serrador hotel in that year of 1947.

Many times, scientific researches, when looking at Camus and the aesthetics of the absurd, passes over the fruitful artistic and aesthetic relationship between Camus' work and the experience of Teatro Experimental do Negro (TEN), hardly researched, as if Camus were the man with wings, the white angel who flew in a story by Gabriel Garcia Marques and who suddenly landed in Duque de Caxias, to the astonishment of the local people, but who disappeared quietly on a ship back to Europe.

But the Hotel Esplanada, in São Paulo, would not go back. I wouldn't do like St. Peter in the Bible. He would deny, deny, deny and continue denying accommodation to an American black woman. It wasn't the Hotel Serrador. Racism was fully institutionalized there. But things wouldn't be like this.

It was Katherine Dunham's white husband who had made the reservation over the phone. That's okay for him, but she wasn't, because Hotel Esplanada didn't know she was black, a discovery made only after the repercussion in the press of the tour of the American group that stayed a month at Copacabana Palace in Rio de Janeiro and moved with the tour to São Paulo. The couple were together on the tour, they had already passed through Cuba and then would go to Chile. They won a difficult event within the US to gain cultural funding for the group.

The decisive action of the black woman Katherine Dunham clashes with the classic of cowardice: "leave it at all". Kind of strong link in support of "cordial racism". Katherine advises an anti-racist stance without daze, ghosts or mirrors. For racist shamelessness the equivalent of anti-racist shamelessness. You eat Bishop Sardinha, as reported by Oswald de Andrade's anthropophagy. Although Oswald, maybe he was a habitué to the Hotel Esplanada in the year 1920's.

The black woman was vaccinated. Inside the US and abroad, racial discrimination, institutional racism in hotels, clubs and nightclubs had already consolidated its unspoken rules. She preemptively prepared herself to react to racism by 
making the denunciation publicly to the press. "Naturally I felt hurt. My life has been a struggle: to show that prejudice is absurd". (Nascimento, 1968, p. 27).

In the US there was a mythical image of Brazil as a racial paradise, arising from studies at Columbia University, whether the pioneer of Rudiger Bilden (unfinished), or the following one by Gilberto Freyre. Brazil was not the US. On the plane to Brazil, the actress had read Casa Grande \& Senzala, in Rio de Janeiro, however, she had contact with two narrative realities: a script of parties and receptions for the American cultural mission by the hands of Gilberto Freyre in points of high society in Rio de Janeiro and another script alongside Abdias do Nascimento. She would draw her own conclusions and push the idyllic vision away from her. The newspaper "O Quilombo" would show him other realities of race relations in Brazil.

Inaugurated at the height of São Paulo coffee, then a successful global commodity, in the early 1920s, the Hotel Esplanada was built by the Prado and Crespo family and also had Guinle's money. It was a luxurious hotel in the center of São Paulo, it was a space of white sociability, with large ballrooms. In the 1950s, the Hotel Esplanada is decadent and later became the headquarters of the company Votorantim, later the São Paulo State Department of Agriculture.

The racist action aimed to shake up and draw attention to its position as a white elite and thereby rescue former clientele. This informs the permanence of institutional racism. But, time does not return.

Refusing to make a reservation at the Hotel Esplanada, the American artist couple stays at the Hotel Marabá. But, during the break of the show's debut, Katherine Dunham climbs on her clogs and "roda a bahiana": she had called a press conference and... pimba... denounces the Hotel Esplanada. The news makes the pages of the Diários Associados newspapers - commanded all around the country by a kind of "Citizen Kane", wins the Brazilian public debate, polarizes political positions within the framework of elections for President of the Republic and for Governor of the State of São Paulo.

\section{FASCIST PRESENCE}

The Italian descendant, businessman and millionaire, candidate for governor of the State of São Paulo in the 1950 elections, Hugo Borghi, will explore and air, in his 
130 radio stations that he came to control, racism and hatred, taking sides in favor of the Esplanade Hotel and against Dunham. This seed of the relationship between racism and fascism in the ground of Brazilian politics is little studied. From the frustrated attempt to control the PTB in the State of São Paulo, as if two Getúlios fit into a single national party, Hugo Borghi created the National Labor Party (PTN), where he obtained, in January $1947,340,562$ votes or $30.5 \%$ of the total and in October 1950, 404,736 or $28.4 \%$ of the votes for governor of the State of São Paulo. Racism had strength. Not having been elected on both occasions, he would be elected federal deputy twice later, ending his political career as federal deputy for Arena, in support of the military dictatorship, in the 1960s.

As governor of the State of São Paulo and in support of his candidate, Adhemar would proselytize against prejudice and "buy" all tickets for the show for two days and invite the black population to watch, in redress, the black dancer and anthropologist Katherine Dunham and your company.

Since 1945, however, there have been signs of censorship on the part of the São Paulo authorities regarding the racial theme developed by the Teatro Experimental do Negro in the State of São Paulo.

\section{FIRST ANTI-RACIST LAW IN BRAZIL.}

To defeat Getúlio Vargas, Afonso Arinos, of the UDN, carved the first antiracist law "by the hands of parliament" in Brazilian parliamentary history. Racism becomes a crime. The 1950 bill, inspired by the case of anthropologist Katherine Dunham, becomes a law sanctioned by Getúlio Vargas in 1951, law 1390/51, which would become known as Lei Afonso Arinos.

This case, based on a lecture by Professor Jerry D'Avila, given at the Faculty of Education at USP, in the first half of 2017, reveals the strength of institutional racism and the potential of anti-racist action, which extends to public policy.

But, as the professor would argue at the time of the lecture, the Afonso Arinos Law, as well as other equivalent actions in Latin America at the time, sought to provide a veneer to camouflage and not overcome racial inequality, a kind of calibrated response to calm the real world later from the absurd horror of the fascist experiences, as if there 
had been no slavery in these parts with a worse plantation of the absurd, of human horror in the process of colonization.

The law, even though it mattered a lot, wouldn't catch on as much. But it would help to postpone the reparations for the accumulated institutional violence, the institutional racism accumulated in the history of Brazil and the perpetuation of the picture of racial inequality.

Thus, pari passu, it would fit as one more piece in the machinery of Brazilian institutional racism and "would curb black claims" in a pan-Africanism contexts of decolonizations.

7. HOTEL MAKSOUD PLAZA AND REPAIRS NOW!

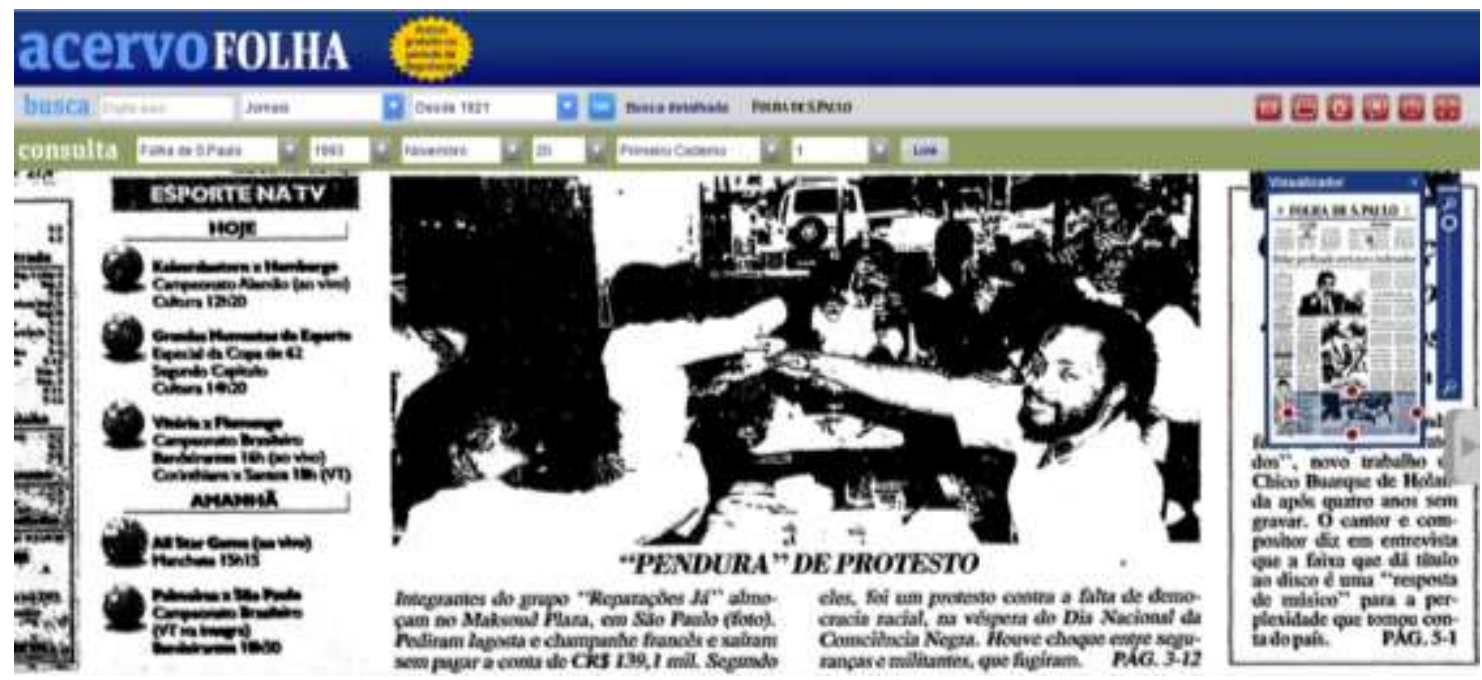

On November 19, 1993, the "impenetrable" luxury hotel Maksoud Plaza, located in the Jardins region, close to Avenida Paulista, São Paulo, would stage an unexpected protest by the black movement. Twelve members would enter the hotel restaurant, eat the best, lobster and French champagne, denounce racial exclusion in Brazil, clamor for reparations now and leave without paying the bill, being chased by the police in the streets of the region. The courageous act, inspired by a theatrical aesthetic, would win the cover of the Folha de São Paulo newspaper on November 20, 1993 and report. A violent theather like the violence of black enslavement. The aim was to alarm society on the eve of Black Consciousness Day in Brazil, the November 20. 
In this episode, the black presence in a white sanctuary aimed at estrangement and the anti-racist action denounced, more than a hundred years after the $\mathrm{i}$ unfinished abolition, the permanence of glaring racial inequalities, the Hotel Maksoud Plaza was symbolic.

\title{
8. THE GHOSTS OF THE HOTELS MAY BE WAITING AND THE CAPOEIRAS TOO!
}

\begin{abstract}
The first black neuroscientist to become a full professor at Columbia University in New York (USA), Carl Hart, 48, says he was stopped on Thursday (27) at the entrance of the fivestar hotel where he would stay and give a lecture to invitation to the seminar of the Brazilian Institute of Criminal Sciences (IBCCrim), in São Paulo. (Fernanda Mena, Folha de São Paulo, 08/29/2015).
\end{abstract}

Hart was not silent.

Diggs might not have been a scientist in 1947, had it not been for the antislavery action of Frederick Douglass in 1873, the formerly enslaved black who would inspire Rebouças in the abolitionist struggle. Perhaps Katherine didn't even have Rebouças' room, if she were in 1873 at the Washington Hotel. Perhaps neurosurgeon Hart "didn't find” a hotel in São Paulo in 2015, it wasn't for Katherine Dunham's bold anti-racist attitude in 1950. For each moment in history, a profile of racism is presented and an anti-racist combat strategy as an equivalent pair.

Perhaps the racism against Rebouças in 1873 was based on a reason where biology had great weight for a pseudo-scientificity of racial hierarchization. Perhaps the racism against Katherine was related to gender, to black women, or perhaps it combines pseudo biological reasons with racist reasons of culture and status. Katherine's antiracist reaction took place in culture. Different types of racism and anti-racism perhaps.

But, there remains racism against blacks, black women and racial inequality, despite undeniable advances. Institutional racism, as seen in hotels, indicates the permanence of racism beyond the subjects, such as the white ghosts present in the Overlook. To overcome institutional racism, the article highlights the importance of public denunciation and the public and collective struggle, of the same group, against the dominant/oppressive group, where the experience of the group of whites and blacks, led by Abdias Nascimento in the case of the Hotel Serrador in Rio de Janeiro in its anti- 
racist action in the Diggs`s case, an action that impacted the birth of an anti-racist public policy, the first anti-racist law in Brazil in the 20th century too.

The study of this article also indicates shadows, even within hotels, for the understanding of institutional racism, and the urgent need to convene this agenda of interdisciplinary studies in academia, as it is one thing to speak abstractly about institutional racism, it is another thing to take stock of their historical occurrences in particular institutions.

Equally important, as a result of this article, is to consider, in the approach to studies on racism, its anti-racist dimension, which perhaps removes castration, passivity and a spontaneous view of racism as a given of nature, but situates it historically and unravels the weapons to fight it and provoke a cultural change in society that needs to be translated into public policies in the fight for black life and against black death. Thus, the translation into public policy is a horizon, not the only one, for collective anti-racist action.

Finally, there are clear clues that racism structures fascism, which is presented in two indicative ways in this study. The first, the position of the candidate for the government of the State of São Paulo, Hugo Borghi, in the 1950 elections, when defending in his speeches the Hotel Esplanada and his racist attitude against Katherine Dunham. The second is the very logic of social dominance, which supports institutional racism, that is, the need for a broad bureaucracy guided by this ethos, because, as Weber teaches, there is no power without bureaucracy. This reinforces the urgent importance of research on institutional racism, because fascism invisibly advances in the world in XXI as a mass movement as the masses are mobilized and if institutional racism occupies a position in one institution, in another, and in another, it indicated the presence, when seen as a whole, of fascism in society, sometimes with the subtleties of disguises and discursive updates, without wearing hoods, but guided by deception, typical of the art of war.

Finally, it is worth recording in the long course of black enslavement in the Americas the deepest foundations of racism, whether in subjects or institutionally, as part of structural racism. Equally profound are the foundations of anti-racism, no doubt about it. 
A theoretical exercise in the construction of typologies of the racism/anti-racism pairs and their historical dynamics is necessary, as well as the fascism/anti-fascism collateral pairs, which requires a longer theoretical undertaking.

\section{References:}

Almeida Jr., Antônio Ribeiro de. Anatomia do trote universitário. São Paulo: Hucitec Editora, 2016.

Alonso, Angela. Flores, votos e balas: o movimento abolicionista brasileiro (1868-88). São Paulo, Companhia das Letras, 2016.

Borges, Rosane. Prefácio. In Kon, Noemi Moritz; Silva, Maria Lucia da; Abud, Cristiane Curi (Organizadoras). O racismo e o negro no Brasil: questões para a psicanálise. São Paulo: Editora Perspectiva, 2017.

Carvalho, Maria Alice Rezende de. O quinto século: André Rebouças e a construção do Brasil. Rio de Janeiro: Revan; Iuperj-Ucam, 1998.

Chalhub, Sidney. A força da escravidão: ilegalidade e costume no Brasil oitocentista. São Paulo: Companhia das Letras, 2012.

Ferreira, Lígia Fonseca (Org.). Com a palavra Luiz Gama: poemas, artigos, cartas, máximas. São Paulo. Imprensa oficial, 2011.

Guimarães, Antonio Sérgio Alfredo Guimarães. A recepção de Fanon no Brasil e a identidade negra. In Almeida, Júlia; Miglievich-Ribeiro, Adelia; Gomes, Heloisa Toller. Crítica pós-colonial: panorama de leituras contemporâneas. Rio de Janeiro: Editora 7Letras/Faperj, 2013.

King, Stephen. O Iluminado. Tradução de Betty Ramos de Albuquerque. Rio de Janeiro. Editora Swarcz S.A., 2020.

Lourenço, Conceição. Racismo: a verdade dói. São Paulo: Editora Terceiro Nome/Editora Mostarda, 2006.

Munanga, Kabengele. As ambiguidades do racismo à brasileira. In Kon, Noemi Moritz; Silva, Maria Lucia da; Abud, Cristiane Curi (Organizadoras). O racismo e o negro no Brasil: questões para a psicanálise. São Paulo: Editora Perspectiva, 2017.

Nascimento, Abdias do. O negro revoltado. Rio de Janeiro: Edições GRD, 1968.

Pinto, Manuel da Costa (Org.). Camus, O viajante: antologia dos textos de Albert Camus sobre o Brasil. Rio de Janeiro, editora Record, 2019.

Ramos, Lázaro. Na minha pele. Rio de Janeiro: Editora Objetiva, 2017. 
Sidanius et all. Social Dominance Theory: its agenda and method. Political psychology, vol. 25, n. 6, 2004.

Silva, Maria Lúcia da. Racismo no Brasil: questões para psicanalistas brasileiros. In Kon, Noemi Moritz; Silva, Maria Lucia da; Abud, Cristiane Curi (Organizadoras). O racismo e o negro no Brasil: questões para a psicanálise. São Paulo: Editora Perspectiva, 2017.

Trindade, Alexandro Dantas. André Rebouças: Um engenheiro do Império. São Paulo: Hucitec, 2011. Coleção Pensamento Político.

\section{CONFLICT OF INTEREST STATEMENT}

The author declares that there is no conflict of interest with this article. 